\title{
ARTICLES
}

\section{WOMEN IN THE WORKPLACE: SHARĪ'AH AND CONTEMPORARY PERSPECTIVES}

\author{
Mohammad Hashim Kamali*
}

\section{Introductory Remarks}

An attempt is made in the following pages to expound Sharicah positions on women's right to work and her freedom to choose the work she undertakes, and then also to own its proceeds regardless of her marital status. It is important to explain the Islamic perspective in this regard as it is influential in determining public perceptions among Muslims even if statutory legislation may have ruled on the rights in question. Yet one of the challenges of general concern is also that the Sharīah positions on women's rights are often conflated with patriarchal customs that undermine women's rights. Women's conditions vary widely among Muslim countries and regions which tend to have cultural characteristics of their own, and face similar but also different challenges. Yet perceptions and attitudes prejudicial to gender equality still persist to the effect that women should stay at home and those who try to secure outside employment should obtain their husband or guardian's permission first. With the exception perhaps of educated professional women in urban centres, women who seek employment opportunities, let alone equal status with men, often risk loss of family support, even being ostracised, especially in places where the conditions of women have not changed much in recent decades.

Custom and culture, prevailing economic conditions, education, urbanisation and a host of other factors all play a role and need to be taken into account in presenting a holistic picture of women, their role and place in the employment sector, society and government generally. The Sharīah is also cognisant of the role of custom and culture and their liability to change in the course of time, and designates, in turn, a number of formulae under the rubric of ijtihäd, general custom ( 'urf) and the maqāsid of Sharī'ah to integrate necessary and beneficial change. It is inadvisable therefore to draw straight analogies and suggest direct 
application of some of the rules of figh that were formulated under different sets of circumstances which differ widely from the conditions prevailing now. This flexibility is also contemplated under the Sharicah principle of permissibility (ibāhah), which is applicable to civil transactions and customary matters ( $m$ ' 'ámalät wa' 'ádät). New developments in these areas are thus deemed to be permissible barring the existence of a prohibition. This is unlike the sphere of beliefs and devotional matters ('aqā'id wa 'ibādāt) to which ibāhah is generally not applied. Work related matters are generally subsumed under mu'āmalāt and 'ādāt, unless there be a specific prohibition based on stronger evidence that precludes the application of ibāhah.

To address the subject before me, I begin with the definition, scope and value of women's right/freedom of work and then review the basic guidelines of the Qur'ān and Sunnah on the subject. Direct recourse to the source evidence is important, not only in its own right, but also due to the medieval social values that crept in over time and influenced the formulation of fiqh rules on women's issues. Even the Qur'ān commentaries were not spared. Patriarchal customary practices and their reductionist impact of women's right also need attention. As one commentator stated, in most cases, it is the custom rather than religious injunction that hindered women's participation in economic activities. In some communities, working women were deemed to have a lower moral standing. ${ }^{1}$ In the event of a discrepancy between a customary practice and the normative ruling of Qur'ān and Sunnah, the former will not be acceptable. Yet in practice such customary positions gradually influenced the attitudes even of scholars and interpreters by the back door, as it were, to influence Qur'ān interpretation and fiqh. ${ }^{2}$ Whereas the Qur'ān actually strengthened the position of women vis-à-vis the then prevailing customs of pre-Islamic Arabia, medieval interpreters often moved in the opposite direction to weaken it.

Then I review the schools and scholars of figh and their positions on the continuity of values or otherwise they may have manifested. When there exist more than one interpretation or opinion in the source evidence, I take a selective approach, in accordance with the Islamic jurisprudence principle of selection (takhayyur), and take that interpretation or view, whether of earlier or modern scholars, that seems more suitable to the conditions of contemporary Muslims.

In dealing with the subject before us, it is important also to bear in mind, not only the particularities of fiqh and contemporary opinion, but also the broader principles of Sharicah that provide guidelines for interpretation and enforcement. This is once again a characteristic aspect of Qur'ān interpretation (tafsir) wherein the general provisions ( 'ám) of the Qur'ān may facilitate a better understanding of its more specific rules so that the general and the specific of the Qur'ān are not totally separated from one another. 


\section{Definition, Scope and Value of Work or 'Amal}

'Amal is basically an economic concept, which is defined as "physical or mental exertion by a human being made for generating economic gain, or for enhancing and developing an existing value." According to another definition "amal consists of self-exertion by a human being either individually or in collaboration with others in order to produce goods or render a particular service." ${ }^{3}$

In modern Arabic writings, expressions such as 'ämil (worker) and its plural 'ummäl, the right of work (haqq al-'amal), and hurriyat al-'amal (freedom to choose one's work and profession) refer mainly to work in its legal and economic senses; yet 'amal also retains its general meaning and it is as such inclusive of religious work that earns one a spiritual reward. 'Amal is a means of earning a living for the individual and of making a contribution to society, just as it is the principal arena of a person's compliance with, or defiance of, God's injunctions.

'Amal is a personal duty of every able-bodied Muslim, and a collective obligation (fard kifá $i$ ) of the community to build the earth and develop its resources for the benefit of humanity. References in the Qur'ān and Sunnah that often occur to 'work with one's hands' have led some to conclude that agriculture, industry, and commerce are the most meritorious of all works as they cater for the basic needs of life, both of humans and other inhabitants of the earth.

The personal freedom and right of individuals to work is inviolable, unless the work in question partakes in infliction of harm (darar) on others, in which case it would fall within the purview of the renowned hadith "Harm may neither be inflicted nor reciprocated in Islam." Work that partakes in harm and corruption is generally unlawful, and so is the revenue that accrues from it. No one may make a business out of defaming others nor profit through acts of oppression. Work that involves prostitution, gambling, sorcery, fraud and immoral behaviour is sinful (ma ssiyah) and must be avoided. The basic rule here is: whatever that leads to harām, or used in order to procure haräm also becomes haräm. A worker is consequently not entitled to any wages for the unlawful work he or she might have completed, and may even become liable to compensation or punishment. ${ }^{4}$

Work that falls between the two categories of haläl and harām should also be avoided if one can find alternative work which is clear of doubt. This would be to act in conformity with the hadith that "One who keeps clear of doubts purifies his faith and his honour." If no other alternative could be found, then one may undertake doubtful work to the extent necessary for the fulfillment of basic needs. Work that is clear of doubt is preferable even if it involves greater hardship. ${ }^{6}$ Should there arise a conflict between the fulfillment of a personal obligation (fard 'ayn) and indulgence in unlawful work, the latter is tolerated, according to some 'ulamä', including Imam Malik, to the extent necessary. 
Suppose that someone lives in a place where no other work to support oneself and family is available except through unlawful work, excluding crimes, and one cannot escape to another place either - one may take it but only to the extent of necessity for survival, but no more than that. ${ }^{7}$ This is equivalent to the concession Shari ${ }^{\mathrm{c}}$ ah has grants to a person who fears death from starvation. According to a legal maxim "necessity (darürah) makes the unlawful lawful," but the necessity in question must, according to another maxim be "measured according to its true proportions." An accurate assessment of necessity would also indicate when it is no longer the case, at which point one must return to the normal rules of Shari ${ }^{\mathrm{c}} a{ }^{8}{ }^{8}$

Work which partakes in fard kifä'i refers to all beneficial work that promotes public welfare such as working in industry and agriculture, health services, education and the like. If some people in the community undertake it, the duty is fulfilled generally, but works of this kind may never be abandoned altogether. In the event when this happens, the government may compel those who are capable of doing so to work. ${ }^{9}$

The most noble of all professions is intellectual work that involves teaching, writing and research. This is because intellectual development is one of the higher objectives, or maqāsid, of Islam and bedrock of all other areas of improvement. This is followed by productive and industrial work that meets people's needs, or which brings great benefit, to the people. Those who occupy themselves with such work earn God Almighty's blessing and reward. ${ }^{10}$ The elderly and the child should not be engaged in strenuous work and it is a responsibility partly of the guardians/relatives and the authorities to ensure that this does not occur. Child labour and assignment of paid work to minors is forbidden unless it has educational value and takes place under supervision of the father/guardian. ${ }^{11}$ Similarly women should not be assigned work that is incompatible with their feminine dignity, and this includes work that brings them into contact with doubtful characters and situations. Women are otherwise permitted to work in trades and professions of their choice. They may work in order to earn a living, for career satisfaction, and use the income they earn from work as they wish. ${ }^{12}$

\section{Review of the Source Evidence}

'Amal (lit, work, action, and conduct) is often used in the Qur'ān, the Sunnah and fiqh literature in conjunction with 'aqidah and 'imän (dogma and faith). This juxtaposition of 'aqidah and 'amal conveys with it the message that the two go hand in hand and that the one is basically deficient without the other. 'Amal in this sense has religious and spiritual undertones and it is often viewed in the Qur'ān and Sunnah as the external manifestation of belief. The close relationship of faith and good deeds is also evident in the typical phrase which occurs in over 
fifty places in the Qur'ān as "those who believe and do good works - al-ladhina $\bar{a}$ manū wa 'amilū al-salihät. The obvious implication is that 'imān and 'amal are intimately related and complement one another.

The spiritual content of 'amal can also be seen in the following Qur'ānic address to the Prophet Muhammad:

Tell the believers to work. Then soon will God, His Messenger and the believers will see the work you have done (Q al-Tawbah, 9:105).

The Prophet is thus directed to remind the people of the value of work and what it takes to make it a source of pride for the community and a firm basis by which to gain the pleasure of God and His Messenger. It is then declared in another verse that "We shall not cause to waste the recompense of one who excels in "amal." (Q al-Kahf, 18:30).

The reference to 'amal in both of these verses is to all works, both pertaining to the affairs of this world and those of the next. This is because in Islam lawful 'amal becomes a dimension of worship ('ibädah) when it is done to the best of one's ability. Work that qualifies as service to God must necessarily be of a high calibre wherein attention is paid to quality and the anticipated outcome, and it is free of dishonesty, cheating and negligence. The Prophet has added his voice in a hadith that "God loves it when a worker undertakes a work that he does it well."13 And declared in another hadith that "No one has ever eaten food purer than what is earned by the toil of one's hands. For the Prophet (cum-King) David, pbuh, used to earn his living by the toil of his hands." 14

These passages are evidently not gender based and apply equally to all. The next verse we quote is explicitly on women's right to work and their exclusive entitlement to what they earn from it. The verse thus declares that "Men are entitled to what they earn and women are entitled to what they earn." (Q al-Nisā, $4: 32)$.

The renowned Qur'ān commentator, al-Tabari (d.923/310), has considered this to be a clear authority on women's right of work. This conclusion is supported by the words used, in particular, nașib (proceeds or result of work), and iktisāb (acquisition), which mean earning something through work. He disagrees with the view that iktisāb in this verse refers to a share of inheritance. Al-Țabarī explains that inheritance is not earned as such, but received without self-exertion and personal labour. Hence those who ignore the difference between iktisāb and mirāth are taking an unacceptable position..$^{15}$ Any attempt to equate inheritance with the fruit of personal labour is likely to go against the spirit of the text and the work ethics of Islam that not only entitles everyone, but make it a duty, in certain situations at least, of everyone to work for their living, and support his or her family. ${ }^{16}$ According to another observer, this verse it also implies that 
women are entitled to take up all suitable occupations they might be capable of undertaking. ${ }^{17}$ The substance of the foregoing has been endorsed elsewhere in the text where God Most High makes it known that "I will not suffer the work of any worker among you to be lost, whether male or female, the one of you being from the other." (Q àli-'Imrān, 3:195).

The late Rector of al-Azhar, Shaykh Mahmūd Shaltūt's commentary on this verse draws attention to the phrase (ba'dukum min $b a^{\prime} d$ ) which eliminates the distinction between men and women in respect of religious and all beneficial work, thereby establishing substantive equality between them. This Qur'ānic language is also indicative of partnership and co-operation between men and women in the work they do within the family and the society at large in the sense that both play equally important roles and there is no superiority of one over the other. $^{18}$

On the subject of authority, or wilayah (also guardianship, protection), the Qur'ān clearly entitles men and women equally to its exercise in respect of one another and in respect, by implication, also of participation in the management of public affairs and government. Thus it is declared that "the believers, men and women, are protectors (awliy $\bar{a}$ ', pl. of wali $)$ of one another, they command good and they forbid evil." (Q al-Tawbah, 9:71).

In addition to validating wilayah for men and women in the sense of cooperation and mutual support, this verse entitles them both to the most comprehensive of all wiläyät, which is to promote good and to prevent evil, also known as hisbah. Hisbah is a broad concept of wide-ranging applications, so much so that government itself is a branch of hisbah, which means that participation in government and leadership in political affairs is a right equally of men and women. Women are consequently entitled, based naturally on qualification and competence, to hold government positions that may involve the exercise of wiläyah in government affairs. ${ }^{19}$ These are further discussed below.

Work from the Shari` ah perspective may be evaluated as either recommendable (mandīb) or obligatory (wajjib), just as it may, in the negative sense, be classified as reprehensible (makrūh) or forbidden (haräm). Work is recommendable if it is beneficial and prevents the individual from dependency on others, poverty and begging. Work that is obligatory may consist either of a personal obligation (fard 'ayn), or a collective obligation (fard kifà' $i$ ). To exert oneself in order to earn a lawful living in the face of dependency and degradation is a personal obligation of every capable individual, especially if one's bodily needs and protection against destruction and disease cannot be met in any other way. Work is also obligatory in order to repay a personal debt, if the debt in question cannot be otherwise repaid. ${ }^{20}$ An able-bodied man is also under a duty to support himself and his immediate family, wife, and children (cf. Q al-Ṭalāq: 65:6, Q al-Baqarah, 2:133). 
This is important, especially in male-dominated cultures where employment opportunities for women are scarce to non-existent.

Muhammad al-Ghazāli (d.1993) and Sādiq Afĩfi ${ }^{21}$ have both concurred with Abū Zahrah (d.1974) to the effect that the Sharī'ah entitles women to work and to earn their living whenever they need to do so or when they can make a special contribution to society. But they add that it is preferable for women to devote their creative energy and work to motherhood since they can make a unique contribution in this area to the well-being of the family and society. It is then added that women may join the workforce in the following four situations:

1. When they have abilities and skills that are particularly valuable to the community as a whole. This is when they excel others, including men, and the role they can play here is considered almost as unique as they can play as mothers and managers of households.

2. When they undertake work to which they are particularly suited such as working in childcare, in health care services and education. Some ulema, including Ibn al-Humām al-Ḥanafi (d.1465 C.E), have considered this kind of work as a collective obligation (fard kifä'i) that applies particularly to women. As for the question of agreement between the spouses, the husband is advised not to stand in the way of his wife when she wishes to work in any of these capacities.

3. When women work side by side with their husbands and family and assist them in their work. This is often the case in the countryside where in farming families, small landholders and other low-income families women assist their men-folk in various capacities, often combining their duties as mothers and household managers with these other activities. Their contributions in these capacities deserve special recognition and "these are the exemplary women of our society; they are hardworking, efficient and compassionate, not like the ones who work as singers and dancers in the night clubs...."

4. When a woman is in need of earning a living to support herself and her family and there is no one else to support her and her family, in which case she would have to work as a matter of necessity. Having said this al-Ghazali added that in an Islamic welfare state, this last category of women are also entitled to support from the public treasury (bayt al$m \bar{a} l)$ regardless of whether she is a Muslim or a non-Muslim. For this is the purport of the hadith in which the Prophet has declared "whoever leaves behind property, it shall belong to his heirs, but if he leaves a debt or dependents in need, they shall be my responsibility."22 


\section{Women as a Witness, Judge and Head of State: Issues Over Wilayah}

Commentators from early times have advanced different views concerning on women's eligibility for public office under the rubric of wilayat, which are of two kinds, public and private. Some maintain that men and women are equal only in the domain of private authority (wilāyah khāșsah), but not in respect of that which involves the exercise of public authority (wilāyah 'ämmah). Wilāyah is defined as the authority of one person over another person or persons which renders the latter bound by the decision of the former without any need for prior agreement. ${ }^{23}$ Private wilayah refers primarily to guardianship over the person and property of another because of some deficiency in the legal capacity of the latter. It is thus stated by the proponents of this binary division and its application to women, that women can be legal guardians and may be employed as teachers, nurses and supervisors of waqf (charitable endowment) but not as ministers, judges and political leaders. ${ }^{24}$

As for women's eligibility for public office which partakes in wilayyah 'ämmah, such as the office of the head of state, prime minister (wazir al-tafwide), judge, governor, officer in charge of market inspection and hisbah, the head of public grievances tribunal (wäli al-mazälim), which partake in both religious and temporal authority, early Muslim scholars have maintained that only the first two are reserved for men but disagree regarding the rest. Abul Ḥasan al-Māwardi (d.1058/450H) thus precluded women from the top two posts as both involved military leadership for which women were not eligible. The main textual authority quoted for this view is the Qur'annic verse, which declared that "men are the maintainers (qawwāmūn) of women for what God has made some of them excel others and for what they spend out of their wealth" (Q al-Nisā', 4:35).

Also quoted is another verse, which provides that "women have rights similar to those that men have over them in a just manner, and men are a degree above them." (Q al-Baqarah, 2:228).

And also the hadith to the effect that "a nation whose affairs are led by a woman shall not prosper."25

General consensus $(i j m \bar{a})$ is often cited in support of the view that only men are eligible for the offices of head of state and prime minister. There is no explicit consensus (al-ijma $\left.\bar{a}^{\prime} a l-s a r i h\right)$ of the learned on record, whether written or verbal, on this, nor is there a clear ruling in the sources to prevent equality even at this level. The most one can say is that it is a practical and a presumptive $i j m \bar{a}$, which has, in any case, been questioned, again in practical terms, by the recent experience of Muslim countries such as Pakistan, Bangladesh, and Indonesia, all of which had elected heads of states and prime ministers - some of whom were 
elected more than once. Hence the $i j m \bar{a}$ in question is not definitive even at the level of practice (i.e., al-ijma $\left.\bar{a}^{c} a l-f i^{\prime} l i\right)$, which is not a binding form of $i j m \bar{a}^{c}$ in any case. ${ }^{26}$

Notwithstanding its weaknesses, however, the $i j m \bar{a}^{r}$ ruling at issue has, in turn, been extended by way of analogy (qiyass) to a number of other public offices, as mentioned above, which are also reserved for men. Imam Abū Hanifah has held, on the other hand, that women may become judges in matters in which they are admissible as witnesses, which means practically all matters except the prescribed penalties $(h u d \bar{u} d)$ and just retaliation (qișass). ${ }^{27}$ To say that women are not eligible for judicial office or that of the head of state, is thus based on analogical reasoning (qiyass), and the original case (așl) here is witnesses, not the office of judge, nor that of the head of state. Ibn Hazm alZāhiri has held, on the other hand, that except for the office of the head of state, women are eligible for all other offices of government. In support of this view, Ibn Hazm has cited the Qur'ānic text on the very subject of government, which provides that "God commands you to hand over the trusts (al-amānatt) to whom that they are due, and when you judge between people, you judge with justice." (Q al-Nisā', 4:58).

Al-amānāt in this text is a reference to public office as a trust and responsibility that may be handed over to the best qualified. Ibn Hazm stated that the verse is perfectly general and draws no distinction between men and women in respect of their eligibility as trustees and repositories of amānāt. The Qur'ān basically envisages everyone as qualified, men and women both, and that we follow the general tenor of its ruling as it is. ${ }^{28}$

As for the above-mentioned hadith, which has been quoted in support of the majority ruling that women are not qualified to become judge or head of state, it is evidently an inference. The hadīth was, as the records indicate, concerned with a particular situation, that is, when the Prophet was informed that the daughter of the Chosroe of Persia had taken charge of the affairs of that country, and this was the Prophet's response to that particular development. It is also noted that the hadith does not contain a ruling but speaks of prosperity and success. Ibn Hazm has commented on this hadith that it refers, in any case, to only one position, namely that of the head of state and does not apply to other public offices (wilāyatt) to which women are generally eligible. More recently, commentators have added the observation that unlike the monarchs or emperors of earlier times, power in a modern state is diffused between its various organs and subjected to a set of constitutional checks and balances in almost all presentday Muslim countries. Under these conditions even when a woman becomes the head of state, her powers would be limited by these factors. The rules of war have also drastically changed, and the head of state-cum-commander-in-chief, 
who was earlier expected to lead the army in the battlefield of jihäd is no longer expected to play that role. The weapons of war now in use dictate a different logic, which is quite the opposite. It would indeed seem patently inadvisable for the head of state to go into the battlefield under the present conditions. ${ }^{29}$ The rules of Islamic jurisprudence also hold that a substantial change in the effective cause and rationale ('illah) of a ruling should be followed by a corresponding change and a suitable ruling $($ hukm) to replace it through ijtihäd.

It may be noted in passing that a group of the Kharijites, namely the Shuhaybiyyah, have held that women are eligible for the office of head of state. ${ }^{30}$ The majority (jumhür) have also held it permissible, as a matter of necessity, for a woman to become head of state if she assumes office by military force in order to prevent bloodshed. But this is only tolerated as the caliphate of necessity, which may only last for as long as it has effective power at its disposal. ${ }^{31}$

A wide spectrum of modern scholars and ulema, including Rashīd Riḍā, Maḥmūd Shaltūt, Muhammad Yusuf Mūsā, 'Abd al-Hamīd Mutawalli and others maintains that women are qualified to be representatives (wakil) in Parliament, ministers, witnesses and judges, all of which partake in the exercise of public authority (wilāyah 'ammah). They have considered the view that sought to confine women's eligibility to the private wilàyät as weak and less than reliable.

The whole debate has come under the scrutiny of the Federal Sharīah Court of Pakistan, which looked into the details and attempted fresh interpretations of Qur'annic verses and hadìth. The FSC came to the conclusion that the two verses above (i.e. $4: 35 \& 2: 228$ ) basically explain one another and the degree that is granted to men signifies leadership in the family on account of their responsibility for the provision of maintenance. That the general equality of the sexes in respect of rights and duties they enjoy has in the meantime, been confirmed by the second of these two texts. Equality is indeed the principal message of this verse; hence the exception made in its latter clause should not be taken so far as to suppress its principal theme. This is not a new interpretation, in fact, as some earlier Qur'ān commentators have also drawn similar conclusions. ${ }^{32}$

\section{Women as Witnesses}

With regard to women's qualification for appointment to judicial posts, the correct interpretation on this is that of the Qur'ān commentator Ibn Jarīr alTabarī (d.310/923) who held, contrary to the then prevailing majority, that women are fully qualified for employment in judicial posts. The majority of the leading schools, as already noted, passed negative judgments on analogy with the position of the head of state. Al-T Tabarī regarded this to be a discrepant analogy (qiyās ma' al-färiq) on the analysis that women judges do not lead the jihad. 
The principal task of a judge is to comprehend and implement the Shari ${ }^{\mathrm{c}}$ ah and attempt ijtihäd, and men and women stand on the same footing in this regard. ${ }^{33}$ Al-Tabarī thus held that women may become judges in all types of disputes, including the hudūd and qișạ..$^{34}$

With regard to women's partial disability to act as witnesses before the courts, my enquiry leads me to the conclusion that there is no clear textual mandate on this in the Qur'ān or authentic hadìth. ${ }^{35}$ The Qur'ānic provision on this occurs only once (Q al-Baqarah, 2:282) and that too in a specific context. The verse thus provides, with reference to money loans and borrowing that it should be clearly documented and testified by "two witnesses from your men. And if two men are not available, then one man and two women of your choice should witness, so that if one forgets, the other woman can remind her. And the witnesses should not refuse when they are called for testimony ..." In their comments on this verse, In Taymiyyah (d. 1328 C.E), his disciple Ibn Qayyim al-Jawziyyah and Mahmud Shaltut observed that the Qur'ānic text here speaks in a language of persuasion and preference, and not in the manner of laying down an injunction. The text also does not preclude the possibility of one woman acting as a witness, or of women being witnesses in a case without there being a male witness. ${ }^{36}$ In view of Islam's unwavering commitment to truth and justice, all avenues that vindicate truth and serve the cause of justice must be left open. If allowing women to give credible testimony in the quest for justice, especially in critical cases where a woman may be holding vital testimony, it should undoubtedly be admitted. The verse is confined to commercial transactions and took into account the conditions of women in Arabia at the time, and those have changed since. The context was such that women were easily pressurised by men, often their male relatives, to revoke their testimony due to subsequent change of circumstances/interests. A second female witness was thus needed to remind her about her testimony and be firm on it as any change could prejudice the cause of justice. ${ }^{37}$

Furthermore, since the ruling under review is specific to financial contracts, it does not apply to other contracts and transactions. A reference is made in this connection to the Qur'ānic ruling over witnesses in imprecation in (Q alNur, 24:6-8) which stipulates that those who accuse their wives and have no witnesses except themselves, let them testify four times, but that the charge will collapse if the wife also testifies four times and rebuts the charge. According to Mahmud Shaltut "four testimonials by a man ... are rebutted by four similar testimonials by a woman, who affirms that she is telling the truth and that the man has lied." Shaltut added that on matters of human dignity and justice, Islam does not discriminate between the sexes." ${ }^{\text {38 }}$ Then also the number specification of two female witnesses equalling one male is not maintained in matters privy to women where one female witness is acceptable. Ibn Qayyim al-Jawziyyah 
thus stated that the Sharicah credits the testimony of one woman as a full proof in matters in which women's familiarity and understanding are considered to be superior to that of men, such as family matters, pregnancy, child birth and so on. ${ }^{39}$ A contemporary commentator adds in confirmation that the present day Muslim countries admit women's testimony in all matters, civil and criminal, without any discrimination and this has now become a matter of general practice. ${ }^{40}$

With reference to qiwämah in financial matters, women enjoy equal ownership rights over what they earn, or receive by way of gift and inheritance, and are fully qualified also to manage their financial affairs, civil transactions and contracts. The Hanafi school has extended this position also to the contract of marriage, which an adult woman can conclude by herself - although the majority of other schools have considered marriage as an exception and require its solemnisation by the legal guardian (wali)), even if the woman is an adult. But then, since Islamic jurisprudence permits selection (takhayyur) among the available rulings of the leading madhhabs, the Hanafi view can be adopted by other schools and has, in fact been so adopted, by other Muslim jurisdictions in the course of $20^{\text {th }}$ century family law reforms. Then there is basically no Shari ${ }^{\mathrm{c}}$ ah issue of concern over an adult women's capacity to conclude her own marriage contract. Yet patriarchal customs among tribal and village populations still present obstacles to women's enjoyment of their financial rights. The problem here is essentially not juridical but one of prejudicial custom and that of male- dominated society. ${ }^{41}$ To give an example, the Qur'ân assigns specified shares in the inheritance to female relatives, which is, however, widely denied to them by their male relatives. Statutory enactments in many Muslim countries that banned such practices on pain of imprisonment and fines have also not succeeded in curbing entrenched customary positions. The lesson one learns here is that prescriptive law reform needs to be followed by wider campaigns on awareness raising, education and supportive policy initiatives. Muslim women in rural Asia and Africa are not well aware of their rights either under the Sharic ah or statutory law. Legislation should naturally be encouraged and continue to lead the way in the campaign for economic empowerment of women. In some particularly difficult situations, recourse may be had to affirmative action legislation and or a quota system, for example, in their admission to schools and employment centres, on a temporary basis at least, to promote the objectives of equal rights for all. ${ }^{42}$

\section{An Historical Sketch}

Broadly speaking, business activity (al-tijärah) was regarded as a respected profession among Arabs, which had also received Qur'ānic approval (cf. Q AlNisa', 4:29). Historical evidence suggests that women were active in business 
and active in the public space during the lifetime of the Prophet, pbuh, and after his demise during the time of the four Rightly-Guided Caliphs. Lady Zaynab bint Jahsh, the wife of the Prophet, used to work in tanning the hides and gave as charity the income she earned from it. Aishah bint Abu Bakr, also the Prophet's wife, was a learned person who was highly regarded by the Companions, many of whom sought her views on juridical issues, especially after the Prophet's demise, when she also became active in politics. It is further reported that the Cleaner of the Mosque of Madinah, at the time of the Prophet, was a woman by the name of Harqa'. ${ }^{43}$ And then also Ra'itah, the wife of the renowned Companion, 'Abd Allah ibn Mas'ud, earned money through handicraft - she asked the Prophet a question whether it was right for her to spend her earning on her husband and child, for they had no other income than what she earned. She added that she could not spare to give any of it in charity. To this the Prophet replied "you also earn a (spiritual) reward by spending on your family. Spend as you wish." 44

Reports also indicate that women traders were active in the market of Madinah, a fact which led the second caliph, 'Umar al-Khattab, to appoint, upon assuming office, a Muslim woman, Shifa' bint 'Abdullah, as Controller of the Madinan Market (Shaykhah Süq al-Madinah). Some women ran businesses with their husband's participation but many did so on their own, and were as such by no means confined to their home. This they did irrespective of their marital status, with the only condition that they be mature and capable to conduct business activity. ${ }^{45}$ Among the noted businesswomen of that period, mention is made of Umm al-Munzir bint Qays, a date trader in the market of Madinah, and Asma' bint Muhkramah bint Jandal, who was a perfume trader. Note also the report: when Qaylah Umm Bani 'Ammar al-Ansariyyah met the Prophet, she explained to him that she was a businesswoman engaged in buying and selling goods, as she wanted to ensure that what she was doing was permissible (halāl). ${ }^{46}$ Many other women of Madinah were engaged in the sale of goods such as cheese, oil and cloth. A second kind of businesswomen of note were those who hired others to run their business, such as Khadijah, Mother of Believers, who engaged Muhammad (later, Prophet Muhammad) to lead her business caravan to Syria. ${ }^{47}$ Women were also active in agriculture, planting seeds, carrying crops, collecting firewood, fetching drinking water, embroidery and handicraft, whereas herding, raising livestock and warfare were mainly conducted by men.

Women also participated in public services and political affairs. 'Arwah bint 'Abd al-Muttalib, was actively engaged in the propagation of Islam during the Makkan period. She visited her relatives to explain Islam to them. Asma' bint Abu Bakr was instrumental in the Prophet's successful migration from Makkah to Madinah. She kept an eye on enemy movements and informed the Prophet and her father Abu Bakr when they were hiding in the cave of al-Nur. ${ }^{48}$ Umm Ayman 
was a courageous woman who became well-known for walking 270 kilometres all alone when she migrated from Makkah to Madinah, for which the Prophet admired and respected her.

Women also took part in jihad and provided support services such as nursing the wounded and providing food and water, and even fighting occasionally. Thus, it is reported that Nusaybah used a sword when she defended the Prophet in the battle of Uhud, and that Umayyah bint Qays al-Ansariyyah participated in fighting in the battle of Khaybar. The Prophet awarded the latter with a necklace for her bravery, which she always wore and even left a will that it should be buried with her when she dies. ${ }^{49}$

Reports further indicate that the women of Makkah and Madinah took part in giving bay'ah (pledge of allegiance) to the Prophet, which he received from groups of Muslims. Historical records indicate that bay'ah was practiced even before its affirmation in the Qur'ān. Thus it is noted that prior to the Prophet's migration to Madinah, two incidents of bay'ah, known as the First 'Aqabah and Second 'Aqabah took place (the latter is also known as Bay'at al-Ridwān), the second of which also included women. Also when the Prophet successfully conquered Makkah in the year 8 Hijrah, many women came to grant him pledge of allegiance. One of them was the legendary Hind bint 'Utbah, wife of Abu Sufyan, a sworn enemy of the Prophet, who had maimed and ripped open Hamzah, the martyred uncle of the Prophet in Uhud. Then when she embraced Islam, the Prophet accepted her bay'ah in the presence of his male Companions in al-Safa. ${ }^{50}$ All of this attests to the fact that the women of Arabia during the time of the Prophet were able to arrange their daily lives such that they could cope both with their work as mothers and wives - and their outside activities. ${ }^{51}$

'Abd al-Halim Abu Shaqqah's encyclopedic work, Tahrīr al-Mar'ah fi 'Asr al-Risālah (liberation of women during the Prophetic era - in six volumes), ${ }^{52}$ is the most exhaustive and widely acclaimed work on its subject to date. Some of the conclusions he has reached in the second volume of his work may be highlighted as follows. He begins by addressing the question whether it is an Islamic requirement for women to be confined to their homes. To this he responds that "participation of women in public life and her meeting with men is the Sunnah of our Prophet, peace be on him." As for the question whether this Sunnah is definitive or open to doubt (qat'i $\bar{\imath}$, or zannī), he states that the total number of reports on this subject, which consists of about 300 hadiths, including the acts, sayings and tacit approvals of the Prophet, when taken together amount to decisive evidence in the rank of Mutawätir. Most of these hadiths are also clear beyond interpretation. Participation (mushärakah) in public life is thus the approved Sunnah.

Abu Shaqqah continued: One can hardly find a sphere of life where encounter 
and participation between men and women did not take place during the time of the Prophet. Available evidence in the Qur'ān and the hadìth collections of al-Bukhari and Muslim indicates that women's participation in the life of the community during this time was dignified, and that dignified encounters took place at the initiative of men and women, as and when the occasion required. Women made their own decisions, and they often met with the Prophet accompanied by their men, other Companions, and occasionally on their own. Women met with women for short times and for longer hours when the occasion so required, within and outside their homes.

On a broader note, one of the reasons many Muslim scholars have attempted fresh interpretation of the source evidence on women's equality is a certain dissonance that exists between the Qur'ānic directives on human equality and justice, and some of the medieval interpretations thereof. This has motivated, as Sa'diyya Shaikh observed, scholars in Egypt, Kuwait, Turkey and the US, including Muslim women, to work on the assumption that much of the unjustified departures from the principles of equality and justice on some aspects of women's rights can be rectified by re-understanding the sacred text. There is a common core of understanding that solutions to the issues concerned must come from the resources of Islam itself. It is further noted that people in different countries and regions, especially Muslims living in the West, tend to relate differently to Islam. Most of the issues relating to women's equality in the workplace, for instance, are not of a great concern for Muslim women residing in the West. They do have other concerns, of course, but this is not a pressing issue to them. For many, it seems, as Shaikh further noted, "Islam is not one among many equally weighted identities but rather a primary source of understanding one's very being in the world." $" 53$

\section{Women in the Workplace: The Malaysian Experience}

I begin with recounting an episode over women's rights that gained media attention in Malaysia in the late 1990s. The debate started with a statement of the then Spiritual Leader of Islamic Party of Malaysia (PAS) and Chief Minister of Kelantan, Nik Aziz Nik Mat, who announced (6 March 1999) that the PAS government (PAS was and still is the ruling Party in the state of Kelantan) would conduct a study with a view to prohibit wives from working. Thus he said: "it was unfair that they should be made to work, which was the responsibility of men." Nik Aziz added that he had no intention of stopping women from work, but that his primary concern was to find ways to ensure that children were not neglected while their mothers were at work. However, he questioned the need for women who worked "secara seronok atau suka-suka" - "just for the fun of it" - but were 
affecting the future of their children. "Islam teaches people to get married so that mothers can look after the children." 54

Nik Aziz further stated that PAS had adopted a ruling which disallowed its women members to stand as candidates in elections, because "it could not guarantee their safety and dignity," and the ruling would also help to prevent women from bergeser (coming into contact with men), for there were groups out to "disturb" women campaigners during elections..$^{55}$ This ruling was said to be temporary and that the party would continue to nominate women Senators. He also stated that PAS already had two women Senators (from Kota Baru and Mekebang), and that the Islamic party had "never prevented its members from supporting women candidates in championing the cause of Islam.. ${ }^{56}$ He further added that he was not questioning the right of widowed women or orphans to seek employment, but was aiming instead at the well-to-do mothers who "work for the sake of money and enjoyment." ${ }^{57}$

One may note here that to say that making an exception for some women, women Senators in this case, appears rather selective and politically expedient. It appears that the women in question were influential and the prohibitive ruling was relaxed in their favour.

Nik Aziz's statements were not well received and prompted negative responses from both government leaders and the media. The then Prime Minister, Dr. Mahathir, said in response that women had their roles and responsibilities "but we cannot separate them and tell them to stay at home. Who are the people selling vegetables at the Kota Baru market?" A reference to the fact, as is generally known, that women participate actively in businesses in Kelantan..$^{58}$

The then Human Resources Minister, Lim Ah Lek, in his comment praised women's contribution to the workforce and said that "it was wrong to even think about the idea. Instead of equal opportunities, it is discrimination and regress for the women as well as affecting the livelihood of the family." He added that it would be an offence under the law to disallow women to work, especially when they want to work, and it is their right to do so. ${ }^{59}$

Utusan Malaysia (daily) carried a commentary to say that "Malaysian women were shocked by the statement." That the achievement of several leading women in business and government did not come overnight but came only after "fighting male prejudice" - adding that PAS was unrealistic to have "presented its narrow opinion" to the people of Malaysia. ${ }^{60}$

Mingguan Malaysia questioned whether PAS leaders can support single mothers who are jobless. Statistics showed that Kelantan recorded a 13\% divorce rate in 1997. Nik Aziz should study the causes, the paper added, and consider the realities that working women were facing. ${ }^{61}$

Pramodini Menon, Vice Chairman of the Malaysian Trade Union Congress's 
Women's Committee commented that earning money is as important as taking care of the children, teaching them and instilling religious values in them. If the man in the family is unemployed, is the government prepared to provide enough for the family? Besides, the right to work is a basic right of women; to take this away devalues women. In 1997, the Malaysian Government proposed to amend the Employment Act to encourage women to come out and work as the country was facing a labour shortage and did not want to be overly dependent on foreign workers. "What has Nik Aziz to say to this?"

Menon added: We are burdened with the reality that many men are not responsible for their women and children. Many women are being divorced every year without getting their due share of maintenance and matrimonial property. Many more children are abandoned by fathers who ignore court orders to provide for them. The real solution is not denying women the right to work; it is to provide them with the support system needed to exercise their rights. This includes affordable childcare centres in the neighbourhood or workplace, flexible working hours and extended maternity leave. ${ }^{62}$

Representatives from seven women organisations of Malaysia also wrote in a commentary that "Nik Aziz Mat's retrogressive comments on women, work and the family are causing much concern to us in the women's movement." This is especially the case in view of the fact that "there is nothing in the Qur'ân or in the hadith which prevents women from working outside the home. In fact the Qur'ān extols the leadership of Bilqis, the Queen of Sheba, for her capacity to fulfill the requirements of the office, for her political skills, her leadership qualities and her independent judgment ..." (Q al-Naml, 27:23-44). Provided a woman is wellqualified and best suited to a task, there is no Qur'ānic injunction to prohibit her from undertaking it because of her sex. The hadīth literature also records many instances of women leaders, scholars and women who fully participated in public life.

Women representatives further added that Malaysians live in a society that encourages women to work and excel academically. Malaysian girls outperform boys in almost all areas of education, reflecting similar worldwide trends. A reference was made to the 1998 statistics for Malaysia, which showed that girls formed 65.3 per cent of the enrollment for pre-university education, and that of the 79,014 university students, 54.5 per cent were female. They also showed that 47.1 per cent of the labour force in 1995 were women. A slightly higher ratio of 60: 40 percent of female to male population in Malaysian universities has been maintained ever since.

At the grass roots level, it was added, that women were "daily confronted with the stark reality that many men are not responsible for their women and children, and also that Muslims record the highest divorce rate in Malaysia." 
All of this points to the fact that women in Malaysia have been actively campaigning for their rights over many decades, and have made significant progress, partly due to a favourable political environment that obtains in this country. An early piece of legislation, a tangible result perhaps of that campaign, was the Pensions (Amendment) Act 1968, which granted equal pay for equal work to men and women alike. Similarly, married women became entitled to file separate income tax assessments under the Income Tax (Amendment) Act of 1975. In 2001, the Women, Family and Community Development Ministry was set up under the then Prime Minister Mahathir. Then came the landmark amendment to Article 8(2) of the Federal Constitution, which prohibited all discrimination based on gender. This was followed in 2004 by a policy initiative under the then Prime Minister Abdullah Badawi to increase women's participation in government and corporate leadership to 30 per cent (as per UN recommendation). Women are as a result being promoted to leadership positions, a policy which has been subsequently endorsed, by the incumbent Prime Minister Najib Razak's administration.

\section{Conclusion and Recommendations}

This paper looked into the issues of women's empowerment in the workplace. Our examination of the source evidence of the Qur'ān and Sunnah, historical data, as well as juristic doctrine is generally affirmative of Islam's essentially egalitarian outlook on women's rights. We have also ascertained the scope and size of the challenges that arise from prejudicial customary practices that undermine women's rights - sometimes contrary to Islamic guidelines. This aspect of the challenge tends to be tenacious and difficult to uproot. Some of the more tangible results of past efforts manifested in reformist legislation have also been surveyed, especially in the case of Malaysia. I now conclude with a set of actionable policy recommendations for follow-up reform as follows:

- Women's right of work is part and parcel of the general challenge of gender equality and justice. Hence it is important that the more particular issues of women's empowerment in the workplace are contextualised into the larger matrix of equality. New solutions to issues should also be related to aspects of equality in matrimonial law, as well as in the economic and social conditions of women in their particular settings.

- Women have always shouldered arduous work as wives and mothers within the family and society, without actually gaining due recognition for it. This should be rectified by due acknowledgment of their contribution as well as grants of material assistance in child benefits and availability of 
child care facilities, health care and adequate maternity leave for working mothers.

- Countries and regions of the Muslim world differ widely in respect of their capabilities, acceptance or otherwise of major changes in women's rights, notwithstanding also their significant commonalities. Particularities of culture and socio-economic conditions must be duly recognised in one's quest and plan for further improvement.

- Islamic law is cognisant of the differences of custom and culture, in so far as these are recognised as valid bases in law and judgment, provided they do not contravene the basic norms of fair play and justice. The theory of ijtihäd is also cognisant of the role of custom in so far as it makes contextualisation of custom and culture of society a pre-condition of ijtihād.

- Islamic law has stagnated nevertheless and a certain disconnect has developed over time, between the Sharī'ah and social reality, as well as statutory legislation. The colonial legacy and its inherent bent on secularist modernity ensured that statutory law in the Muslim world is not energised by the guidelines of Qur'ān and Sunnah or the resources of ijtihadd, but by a wholesale importation of western laws and institutions into their former colonies.

- Gender equality in the workplace still looms large and remains a challenge unmet in the larger part of the Muslim world, not so much because of a lack of statutory law and policy, but that much of what already exists is prescriptive and wanting of effective implementation. A lesson to be learned may be that law and policy making on gender issues need to be action-oriented. It is better to be gradual and effective rather than idealistic and ambitious beyond context.

- Our village folks, religious leaders and conservative strata of population have often remained uninvolved or aloof to the issue of women's rights and the efforts to address them at the level of law and policy. These efforts need to be more inclusive and reach out for the people's consultative input. Law and policy should be such that people can relate to and understand. The importance of enlisting the support of imams and religious leaders to the gender justice campaign can hardly be overestimated.

- Muslims need to own the agenda of gender justice themselves. The fact that this has hitherto been largely driven by western ideas has generated internal resistance among Muslims - sometimes even among those who may otherwise be less than hostile to reform. For Muslims to own that agenda is to anchor it in local culture and Islam. One can still keep an open outlook on beneficial input from other traditions, but only when 
substantive harmony with indigenous values is carefully ascertained in one's quest for overall improvement.

- Gender justice issues are closely tied to the Muslim perceptions of piety, which adds to religious sensitivities. Even in the fiqh tradition, the subject of matrimonial law (munākahāt) features next, in the order of thematic classification, to devotional matters ( $\left.{ }^{i} i b \bar{a} d \bar{a} t\right)$, due to the recognition that marriage has a devotional ( $t a{ }^{\prime} a b b u d \bar{l}$ ) aspect and is different in that respect from the rest of civil transactions (mu'àmalāt). All this notwithstanding, the fact remains that marriage is a civil contract in Islamic law.

- It is advisable for western sponsors and advocates of women's equality to recognise in their supportive projects and programmes in Muslim countries, or the most conservative among them at least, that an openly assertive stance on gender issues can be counter-productive.

- Gender justice campaigns by the Muslims themselves should approach the outstanding problems according to a carefully graduated approach that takes up the relatively softer issues, such as education, literacy, and healthcare before they move on to the more challenging problems of reform on core issues of local custom, matrimonial law and inheritance. Women's equality in the workplace too is internally diverse. For instance, employment of women in certain professions, such as medical services, teaching, social and family support sectors are not as sensitive as their participation in elected assemblies, police and prison services and the like. Gradualism and pragmatism also avail one of the benefits of selfassessment over time.

- Finally, some Muslim countries, such as Malaysia, Indonesia, Morocco, Turkey and even Egypt can perhaps form a common platform to act in unison in the advancement of gender justice in other parts of the Muslim world. Some of these countries enjoy better prospects of receptivity and cooperation with other Muslim countries. The countries just mentioned may consider participation in projects that seek to strengthen the family unit, local economy and education with the significant participation of women themselves. 


\section{Notes}

* Mohammad Hashim Kamali, Founding CEO of IAIS Malaysia, graduated from Kabul University, and took his PhD in Islamic and Middle Eastern Law at the University of London in 1969. Professor Dr M. H. Kamali served as Professor of Islamic Law and Jurisprudence at the International Islamic University Malaysia (IIUM, 19852007), then Dean of the International Institute of Islamic Thought and Civilization (ISTAC). He also held Visiting Professorships at McGill University's Institute of Islamic Studies; Capital University, Ohio; and the Wissenschaftskolleg, Berlin. A member of the Constitution Review Commission of Afghanistan (2003), he has provided expert legal consultation to the new constitutions of Iraq, the Maldives and Somalia. Eminent authority on Islamic legal studies, he has published over 170 academic articles and 35 texts, including standard textbooks at universities worldwide. He can be contacted at ceo@iais.org.my.

1. Faisal Osman, Women, Islam and Nation Building, Kuala Lumpur: Penerbit Fajar Bakti, 1992, p. 23. See also Salwa al-Khamsah, Al-Mar'ah al-'Arabiyyah wa'lMujtama'al-Taqlīìi al-Mutakhallif, Beirut: Dar al-Haqiqah, 1973, p. 22.

2. Cf., Jamal al-Banna, Nahw al- Fiqh al- Jadìd, Cairo: Dar al-Fikr al-Islami, 1996, p. 197.

3. See for both these definitions Mohammad Hashim Kamali, The Right to Education, Work and Welfare in Islam, Cambridge: The Islamic Texts society, 2010, p. 96 quoting al-Qaradawi, Mushkilat al-Faqr, and al-Dughmi, Nazariyyat al-Amn.

4. See for details Kamali, The Right to Education, Work and Welfare, p. 118f.

5. Al-Bukhari, Sahīh al-Bukhārī, kitäb al Imān, b. min fadl man istabra'a li-dīnihi, hadìth no. 50; Muslim, Sahịh Muslim, k. al-musāqāt, b. akhdh al-halāl wa tark alshubhät, hadìth no. 2996.

6. Cf., Abd al-Wahhab al-Shishani, Huqūq al-Insān wa Hurriyatuh al-Asāsiyyah fi'l-Nizām al-Islämī wa'l-Nuzūm al-Mu'äsirah, Amman: Matabi' al-Jami'yah alMalakiyah, 1980/1400, 458.

7. Abu Ishaq Ibrahim al-Shatibi, al-I'tișām, Cairo: Matba'ah al-Manar, 194/1332, II, 300; Shishani, Huqūq al-Insān, 457. Shatibi wrote that al-Ghazali and Ibn al-'Arabi held similar views.

8. See for details, Kamali, The Right to Education, Work and Welfare, p. 119.

9. Cf. Abu Zahrah, Tanzìm al-Isläm li' 'l-Mujtama', Cairo: Matba'at al-Mukhaymir, n.d., p. 51.

10. Cf., al-Qaradawi, fi Fiqh al-Awlawiyät, Dirāsah Jadīdah fi Daw' al-Qur'ān wa'lSunnah, $2^{\text {nd }}$ edn. Cairo: Maktabah Wahbah, 1996/1416, 119.

11. Yahya ibn Sharaf al-Nawawi, Rawdat al-Tãlibin, Beirut: al-Maktab al-Islami, 1975/1395, v, 250; Muhammad Rakan al-Dughmi, al-Nazariyyat al-Amn al-Ghaza'i min Manzūr al-Islāmī, Amman (Jordan), Yutlab min al-Mu'allif, 1988/1408, 78.

12. Cf., al-Shishani, Huqūq al-Insān, 535; Isma'il Badawi, Da'ä'im al-Hukm fi'lShari'ah al-Islamiyyah wa'l-Nuzüm al-Dustüriyyah al-Mu'āsirah, Cairo: Dar al-Fikr al-‘Arabi, 1980/1400, p. 404.

13. Muslim, Mukhtașar Sahīh Muslim, ed., Muhammad Nasir al-Din al-Albani, $2^{\text {nd }}$ edn., Beirut: Dar al-maktab al-Islami, 1984/1404, p. 327, hadìth 1, 201.

14. Al-Tabrizi, 'Abd Allah al-Khatib, Mishkāt al-Mașäbīh, ed., Muhammad Nasir al-Din al-Albani, $2^{\text {nd }}$ edn., Beirut: al-Maktab al-Islami, 1979/1399, Vol. II, hadith 2, 759. 
15. Muhammad ibn Jarir al-Tabari, Tafsìr al-Tabarī, Cairo: Dar al-Ma'arif, 1969, VIII, p. 267.

16. Cf., Faisal bin Haji Othman, Women, Islam and Nation Building, pp. 19-20.

17. Musin a1-'Abūdi, A1-Hurriyyāt al-Ijtimā'iyyah, bayn al-Nuzūm al-Mu'āsirah wa'lFikr al-Islāmī al-Siyāsī, Cairo: Dar al-Nahdaha al-'Arabiyyah, 1990/1410, p. 84.

18. Shaltut, Al-Islām 'Aqìdah wa Sharī'ah, Kuwait: Matabi’ Dar al-Qalam, n.d., p. 195.

19. 'Abd al-Hamid al-Shawāribi, al-Huqūq al-Siyāsiyyah li'l-Mar'ah fi'l-Islām, Alexandria (Egypt): Mansha'at al-Ma'arif, 1987, p. 85f.

20. Muhammad ibn Hassan al-Shaybani, A1-Kitāb fi'l-Rizq al Mustatāb, ed. Muhammad ibn Sama'ah, Cairo: Maktabah Nashr al-Thaqafah al-Islamiyyah, 1940/1357, p. 32; Badawi, Da'à'im, p. 381; al-Shīshāni, al-Hurriyyāt al-'Āmmah, p. 307.

21. Muhammad al-Ghazāli, Huqūq al-Insān bayn Ta'lìm al-Islām wa I'lān al-Umam alMuttahidah, Alexandriah (Egypt): Dar al-Da'wah li'l-Nashr wa'l-Tawzi', 1993/1413, pp. 134-136. See also Muhammad al-Sādiq 'Afífi, al-Mujtama' al-Islāmi wa Ușul al-Hukm, Cairo: Dar al-I’tisam, 1980/1400, pp. 209-211.

22. Hadith reported by all the major collections of hadith (i.e. muttafaqun 'alayh): alBukhari, Sạ̄ịh al-Bukhāri, III, p. 155.

23. 'Abd al-Razzaq al-Sanhūri, Fiqh aI-Khilāfah wa Tatawwuruhā, eds. Nadia al-Sanhuri and Tawfiq Muhammad al-Shawi, Cairo: al-Hay'ah al-Misriyyah li'l-Kitab, 1989, p. 187.

24. Cf. 'Abd al-Hamid Mutawalli, Mabādi Nizām al-Hukm fi'l-Islām, Alexandriah (Egypt); Mansha'at al-Ma'arif, 1974, p. 417.

25. Tabrizi, Mishkät, Vol. II, hadìth 3693.

26. See for details on the varieties of $i j m \bar{a}^{c}$ Mohammad Hashim Kamali, Principles of Islamic Jurisprudence, $3^{\text {rd }}$ edn., Cambridge: Islamic Texts Society, 2003, p. 248f.

27. Abul Hassan al-Māwardi, Kitāb al-Ahkām al-Sultāniyyah, $2^{\text {nd }}$ edn., Cairo: Matba'ah al-Babi al-Halaby, 1966/1386, p. 65.

28. Muhammad b. 'Ali b. Ahmad b. Sa'id al-Zahiri, A1-Muhallā, ed. Hasan Zaydān, Vol. X, p. 632; al-Mawardi, Aḥām, p. 64.

29. For a discussion of the source evidence on reserving the position of the head of state for men, see Kamali, Freedom, Equality and Justice, pp. 63-65.

30. Ibn Hazm al-Zahiri, al-Fisal fi'l-Milal wa'l Ahwa' wa'l-Nihal, Cairo: Maktabah Salam al-'Alamiyyah, n.d., Vol. IV, p. 167.

31. Al-'Īli, al-Hurriyyāt, p. 288.

32. See for details Kamali, Freedom, Equality and Justice, p. $65 \mathrm{f}$.

33. See for details on Ibn Jarir al-Tabari's view, Kamali, Freedom, Equality and Justice, 66-70.

34. Ibid., pp. 66-70.

35. Ibid., pp. 66-69.

36. Ibn Qayyim al-Jawziyyah, al-Turuq al-Hukmiyyah fi'l-Siyāsah al-Shar'iyyah, ed., Muhammad Jamil Ghazi, Jeddah: Maktabat al-Madani, n.d., p. 149.

37. Cf., Amina Wadud-Muhsin, Qur'ān and Women, Kuala Lumpur: Penerbit Fajar Bakti, 1992, pp. 85-86.

38. Mahmud Shaltut, al-Islām, 'Aqīdah wa Sharīah, p. 253.

39. Ibn Qayyim, al-Turuq, 152. For a fuller discussion of this issue Mohammad Hashim Kamali, Freedom, see Equality and Justice in Islam, pp. 67-69.

40. Fawziah al-'Ashmawi, “Tajdīd al-Fikr al-Islāmī: Manhaj al-Ta'āmul ma' Qaḍāyā 
al-Mar'at al-Muslimah," in ed. Mahmud Hamdi Zaqzuq, Tajdìd al-Fikr al-Islāmī: Buhūth wa Fa'aliyyāt al-Mu'tamar al- 'ām al-Wähid wa'l- 'Ishrīn li'l-Majlis al-A'là li'l-Shu'ūn al-Islämiyyah, Cairo, 2009/1430, p. 705.

41. See for details on the role of patriarchal custom in Muslim countries Maimul Ahsan Khan, Islamic Jurisprudence and Women's Rights, Bangladesh: The Nahar Light Foundation, 2007, p. 207f.

42. Cf., Mohammad Hashim Kamali, Shari'ah Law: An Introduction, Oxford: Oneworld Publications, 2008, pp. 271-72.

43. Ibn Hajar al-'Asqalani, al-Isābah fi Tamyīz al-Sahābah, Cairo: Dar al-Azhar, 1977, XII, p. 221.

44. Abu 'Ubay al-Qassim ibn Salam, Kitāb al-Amwāl, Eng. Tr. by Noor Muhammad Ghiffari entitled as The Book of Finance, Islamabad, Hijra Council, 1991/1411, p. 490.

45. al-‘Asqalani, al-Ișābah, XIII, pp. 4-5.

46. Ibid, XIII, 106.

47. Cf., Faisal Othman, Women, Islam and Nation Building, p. 28.

48. Al-'Asqalani, al-Isābah, XII, 114.

49. 'Ali 'Abd al-Wahid Wafi, al-Musāwāt fi'l-Islām, Cairo: Dar al-Ma'arif, 1965, p. 45.

50. al-'Asqalani, al-Ișābah, XIII, 165-66. See also Faisal Othman, Women, Islam and Nation Building, p. 46.

51. Cf., Faisal Osman, Women, Islam and Nation Building, p. 30.

52. Abd al-Halim Abu Shaqqah, Tahrīr al-Mar'ah fi 'Asr al-Risālah ${ }^{52}$ Dirāsah Jāmi'ah li-Nusūṣ al-Qur'ān al-Karìm wa Sahīh al-Bukhārī wa Muslim, Kuwait, 1990/1410, Vol. II.

53. Sa'diyya Shaikh, "Transforming Feminisms: Islam, Woman and Gender Justice," in ed. Omid Safi, Progressive Muslims, on Justice, Gender and Pluralism, Oxford, Oneworld Publications, 2003, p. 156.

54. Reported in The Star daily of Kuala Lumpur, March I8, 1999, p. 14.

55. Quoted in The Star article "PAS Ruling to 'Protect Women'," March 25, 1999, p. 2.

56. Id.

57. "Debate over Nik Aziz's view on working women," The Star, Kuala Lumpur, March 27, 1999, p. 20.

58. Reported in The Star, Kuala Lumpur, March 22, 1999, p. 2.

59. “PAS Proposal Draws Scorn,” The Star, Kuala Lumpur, March 18, 1999, p. 14.

60. Id.

61. Id.

62. Pramodini Menon, "Women Have the Right to Choose," The Star, March 25, 1999, p. 22.

63. Cf., Sharifah Hapsa Shahabudin, "Women have come a long way," Kuala Lumpur: New Straits Times, January 29, 2013, p. 15.

64. "Denying Women Right to Work Deprives Them of Choice," New Straits Times, Kuala Lumpur, March 20, 1999. The seven women groups mentioned were: Sisters in Islam, All Women's Action Society, Pusat Khidmat Wanita Pertiwi, Women's Aid Organisation, Women's Crisis Centre, and Women's Development Collective. It was added that the 1997 statistics from the Selangor Syariah Court showed that out of 2,165 registered divorces, only 29 were granted a mut'ah (consolation gift), 58 were on division of matrimonial property, 55 of wife maintenance, 63 of child 
maintenance, and only ten cases of 'iddah maintenance. This "abysmal record from one of the most developed states in Malaysia is a tragic reflection of how far reality is from the Qur'anic ideal of responsible Muslim male." Noted also was the experience of single mothers which showed that their standard of living plunged immediately after divorce or desertion and fell into the poverty trap, while their ex-husbands tended to experience little change in their living standards.

65. See for details Sharifah Hapsa Shahabudin, NST article as above. 